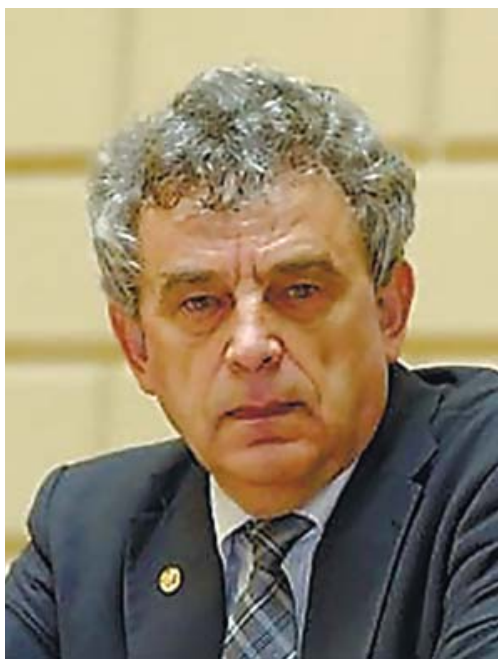

ЯЦЕНКО

Леонід Петрович академік НАН України, голова Національного фонду досліджень України, завідувач відділу когерентної та квантової оптики Інституту фізики НАН України

\section{НАЦІОНАЛЬНИЙ ФОНД ДОСЛІДЖЕНЬ УКРАЇНИ - НОВІ МОЖЛИВОСТІ ДЛЯ НАУКОВЦІВ АКАДЕМІЇ}

Вельмишановний Анатолію Глібовичу!

Вельмишановні колеги!

Мій виступ має на меті ознайомити вас з діяльністю Національного фонду досліджень України. Однак, перш ніж звернутися до основної теми, я хотів би підтримати пропозицію, яка вже пролунала у виступах попередніх доповідачів, - схвалити доповідь президента НАН України і вважати роботу Національної академії наук у звітному році задовільною. Крім того, як голова постійної комісії НАН України з оцінювання ефективності діяльності наукових установ хотів би висловити вдячність президенту НАН України за високу оцінку її діяльності і висновки про важливість роботи в цьому напрямі.

Отже, діяльність Національного фонду досліджень України регулюється насамперед Законом України «Про наукову і науково-технічну діяльність», в якому було визначено його статус та основні завдання. У ст. 49 цього закону записано: «Національний фонд досліджень України є державною бюджетною установою, основним завданням якої є грантова підтримка: 1) фундаментальних наукових досліджень у галузі природничих, технічних, суспільних та гуманітарних наук; 2) прикладних наукових досліджень і науково-технічних (експериментальних) розробок за пріоритетними напрямами розвитку науки і техніки».

Хочу привернути вашу увагу до цього пункту закону у зв'язку з дискусією, яка виникла сьогодні, щодо формування МОН України нового переліку пріоритетних напрямів розвитку науки і техніки та інноваційної діяльності. Там дійсно немає вимоги щодо грантової підтримки фундаментальних досліджень тільки за пріоритетними напрямами, оскільки у процитованому фрагменті закону пріоритетні напрями стосуються лише прикладних досліджень і науково-технічних розробок. Однак зараз триває громадське обговорення запропонованих МОН України змін до Закону України «Про наукову і науково- 
технічну діяльність», які, зокрема, стосуються i ст. 49 цього документа. Там є пропозиція, щоб гранти Національного фонду досліджень України на фундаментальні дослідження також розподілялися за пріоритетними напрямами. Якщо такі зміни буде ухвалено і буде затверджено список пріоритетів без фундаментальних досліджень (як це запропоновано наразі), то Фонд не зможе фінансувати проєкти, наприклад Інституту теоретичної фізики ім. М.М. Боголюбова НАН України.

У чинному законі також записано, що частина фінансування наукової і науково-технічної діяльності (яке загалом мало б становити не менш як 1,7\% ВВП) за рішенням Національної ради України з питань розвитку науки і технологій спрямовується на конкурсне фінансування проєктів через Національний фонд досліджень України і щороку збільшується. Причому це збільшення грантового фінансування не може відбуватися за рахунок зменшення базового фінансування основної діяльності наукових установ та організацій, оскільки видатки на наукову і науково-технічну діяльність $€$ захищеними статтями видатків Державного бюджету України. На жаль, у реальності не все виходить так добре.

Структура Національного фонду досліджень України складається з голови, який організовує його роботу; Наглядової ради, яка визначає загальну стратегію Фонду та здійснює загальну координацію і контроль за його діяльністю (iї функції покладаються на Науковий комітет Національної ради України з питань розвитку науки і технологій); Наукової ради, очолюваної головою Фонду, яка відповідає за формування умов конкурсів, визначення пріоритетів, координацію та контроль проведення експертизи і відбору проєктів; дирекції на чолі з виконавчим директором, яка надає технічну та організаційну підтримку у проведенні конкурсів, забезпечує діяльність Фонду як державної бюджетної установи. Функції з управління Фондом виконує Кабінет Міністрів України.

Оцінка проєктів, які претендують на грантову підтримку Фонду, здійснюється незалеж- ними експертами у відповідних галузях науки і техніки. Ані Наукова рада, ані дирекція Фонду не мають можливості втручатися в процес проведення експертизи. Грантова підтримка досліджень і розробок обов'язково передбачає прозорий публічний конкурсний відбір, який здійснюється незалежно від відомчої належності дослідників. Учасниками конкурсних відборів можуть бути юридичні особи будьякої форми власності. Рішення про надання грантового фінансування конкретному проєкту є колегіальним, його приймає Наукова рада на основі результатів проведеної експертизи.

У 2020 р. Національний фонд досліджень України було профінансовано в розмірі 271,7 млн грн, що еквівалентно 8,17 млн євро. Для порівняння наведу минулорічні обсяги фінансування аналогічних структур в інших країнах:

- Естонська дослідницька рада - 42,7 млн євро;

- Чеський науковий фонд - 160 млн євро;

- Польський національний науковий центр 1,17 млрд євро;

- Японське товариство сприяння науці 2,22 млрд євро.

Як бачите, нам ще дуже далеко не лише до сусідньої Польщі, а й навіть до невеличкої Естонії.

Створювався Національний фонд досліджень України дуже тяжко. Минуло майже п'ять років, поки ми змогли торік розпочати реальну роботу. Однак, як ви знаєте, тоді почалася пандемія COVID-19 і кошти, передбачені в бюджеті України в 2020 р. на діяльність Фонду, в корегованій версії бюджету планувалося повністю передати в «ковідний» фонд. Для прийняття такого бюджету у Верховній Раді України забракло лише кілька голосів, тому певне фінансування ми все ж отримали, великою мірою завдяки тому, що Фонд вирішив проводити не один великий конкурс, а два «Підтримка досліджень провідних та молодих учених» i «Наука для безпеки людини та суспільства», тематика якого переважно була спрямована на подолання медико-біологічних, економічних, соціальних, психологічних, 
Табл. 1. Результати конкурсів, проведених Національним фондом досліджень України у 2020 р

\begin{tabular}{|c|c|c|c|c|}
\hline \multirow{3}{*}{ Наукові галузі } & \multicolumn{4}{|c|}{ Конкурси } \\
\hline & \multicolumn{2}{|c|}{$\begin{array}{c}\text { Підтримка досліджень } \\
\text { провідних та молодих учених }\end{array}$} & \multicolumn{2}{|c|}{$\begin{array}{l}\text { Наука для безпеки } \\
\text { людини та суспільства }\end{array}$} \\
\hline & $\begin{array}{c}\text { Подано } \\
\text { заявок }\end{array}$ & $\begin{array}{l}\text { Виграно } \\
\text { проєктів }\end{array}$ & $\begin{array}{c}\text { Подано } \\
\text { заявок }\end{array}$ & $\begin{array}{l}\text { Виграно } \\
\text { проєктів }\end{array}$ \\
\hline Природничі, технічні науки і математика & 257 & 100 & 172 & 28 \\
\hline Біологія, медицина, аграрні науки & 88 & 27 & 203 & 26 \\
\hline Соціальні і гуманітарні науки & 70 & 14 & 141 & 23 \\
\hline Загалом & 415 & 141 & 516 & 77 \\
\hline
\end{tabular}

гуманітарних і культурних наслідків пандемії коронавірусної хвороби.

На обидва конкурси подано було 931 заявку, з них оцінено всього 737 заявок, переможцями стали 218 проєктів, а фінансування отримали 216 проєктів.

Так, на конкурс «Підтримка досліджень провідних та молодих учених» було подано 415 заявок від 178 установ; експерти оцінили 316 заявок - 585 залучених експертів надали 1131 експертну оцінку, зокрема 152 оцінки від іноземних експертів. Переміг 141 проєкт з 69 установ (прохідний бал становив 87,3) (табл. 1). Строк виконання проєктів за цим конкурсом становить 3 роки; загальний обсяг фінансування на весь період передбачено у розмірі 975126500 грн. У 2020 р. виділено 136,9 млн грн.

На конкурс «Наука для безпеки людини та суспільства» було подано 516 заявок від 228 установ; експерти оцінили 421 заявку - 567 залучених експертів надали 1531 експертну оцінку, зокрема 152 оцінки від іноземних експертів. Перемогли 77 проєктів 344 установ (прохідний бал становив 83,1) (табл. 1). Строк виконання проєктів за цим конкурсом становить 2 роки; загальний обсяг фінансування на весь період передбачено в розмірі 398627226 грн. У 2020 р. виділено 118,4 млн грн.

На проведення експертизи за обома конкурсами витрачено 1,615 млн грн.

Тепер кілька слів про те, як розподілилися проєкти-переможці за відомчою належністю організацій-грантоотримувачів. Як можна ба- чити 3 табл. 2, установи НАН України вибороли більш як половину проєктів $(51,8 \%)$ за конкурсом «Підтримка досліджень провідних та молодих учених», але за конкурсом «Наука для безпеки людини та суспільства» результати Академії дещо скромніші (46\%).

Якщо розглянути рейтинг грантоотримувачів за кількістю проєктів-переможців, то за конкурсом «Підтримка досліджень провідних та молодих учених» лідером є Київський національний університет імені Тараса Шевченка 14 проєктів, наступні позиції посіли Інститут теоретичної фізики ім. М.М. Боголюбова НАН України -6 проєктів, Інститут молекулярної біології і генетики НАН України, Львівський національний університет імені Івана Франка, Національний технічний університет України «Київський політехнічний інститут імені Іго-

Табл. 2. Розподіл проєктів-переможців за відомчою належністю організацій-грантоотримувачів, у \% від загальної кількості

\begin{tabular}{|l|c|c|}
\hline \multirow{2}{*}{$\begin{array}{c}\text { Відомче } \\
\text { підпорядкування } \\
\text { організацій- } \\
\text { грантоотримувачів }\end{array}$} & $\begin{array}{c}\text { Підтримка дослі- } \\
\text { джень провідних } \\
\text { та молодих учених }\end{array}$ & $\begin{array}{c}\text { Наука для без- } \\
\text { пеки людини та } \\
\text { суспільства }\end{array}$ \\
\hline НАН України & 51,8 & 46,0 \\
Заклади \\
вищої освіти \\
$\begin{array}{l}\text { Галузеві } \\
\text { академії наук }\end{array}$ & 46,8 & 42,2 \\
Інші & 1,4 & 10,5 \\
\end{tabular}

ISSN 1027-3239. Visn. Nac. Acad. Nauk Ukr. 2021. (6) 
ря Сікорського» і Сумський державний університет - по 5 проєктів.

За конкурсом «Наука для безпеки людини та суспільства» першу позицію рейтингу також займає Київський національний університет імені Тараса Шевченка - 10 проєктів, потім ідуть Інститут молекулярної біології і генетики НАН України - 6 проєктів, Національний технічний університет України «Київський політехнічний інститут імені Ігоря Сікорського» і Сумський державний університет - по 5 проєктів, Національний університет «Львівська політехніка» -3 проєкти.

На фінансування Національного фонду досліджень України в 2021 р. передбачено в державному бюджеті 732 млн грн, що становить лише $95 \%$ від необхідного обсягу фінансування вже розпочатих проєктів.

Укладати договори з грантоотримувачами на виконання проєктів у поточному році ми почали з великим запізненням, оскільки з початку року Наукова рада Фонду була нелегітимною, і лише 17 березня було затверджено її оновле- ний склад. Після цього ми провели 15 засідань, на яких затвердили укладені на 2021 р. договори, і з 1 травня переважна більшість проєктів нарешті отримали фінансування.

Також у 2021 р. попередньо заплановано проведення трьох конкурсів 3 поки що умовними назвами: «безпековий», «обладнання» та «інформаційні технології. У рамках «безпекового» конкурсу, можливо, будуть брати участь проєкти за відкритою військовою тематикою. «Обладнання» - це конкурс наукових проєктів, у якому за додатковим обгрунтуванням можливим буде виділення до 30 млн грн на придбання наукових приладів.

Однак оскільки фінансування Фонду в поточному році не передбачає грантової підтримки нових проєктів, ми плануємо провести ці конкурси, але з початком фінансування проєктів-переможців уже з 2022 р.

Отже, запрошуємо науковців НАН України до участі в конкурсах Національного фонду досліджень України.

Дякую за увагу! 